\title{
Comparative evaluation of the effectiveness in plaque removal from the tooth surface by electric toothbrushes with different types of bristle movement
}

\author{
V.G. Atrushkevitch ${ }^{a}$, V.N. Tsarev ${ }^{a}$, L.Yu.Orekhova ${ }^{\text {b }}$, L.A. Elizova ${ }^{c}$, E.S. Loboda ${ }^{d}$ \\ aMD, PhD, DMSci, Professor, A.I. Yevdokimov Moscow State University for Medicine and Dentistry, Moscow, Russia \\ ${ }^{b} \mathrm{MD}, \mathrm{PhD}$, DMSci, Professor, Pavlov First Saint Petersburg State Medical University, Saint Petersburg, Russia \\ ${ }^{c} \mathrm{MD}$, PhD, A.I. Yevdokimov Moscow State University of Medicine and Dentistry, Moscow, Russia \\ ${ }^{\mathrm{d} M D}$, PhD, Associate Professor, Pavlov First Saint Petersburg State Medical University, Saint Petersburg, Russia
}

doi: $10.32993 /$

stomatologist.2018.4(31).11

Received 26.10.18

Accepted 30.10.18

Keywords:

microbial biofilms,

periodontitis,

electric toothbrushes

\begin{abstract}
Supportive periodontal therapy (SPT) is an important factor in maintaining the results of active treatment of periodontal disease. Selection of effective personal hygienic tools is very important in addition to the formation of sustainable hygienic skills in patients. The aim of the study is a comparative assessment of the quality of mechanical removal of a native microbial biofilm with toothbrushes with different types of head rotation and a manual toothbrush. Objects and methods. The extracted teeth were fixed in plaster models, and the vestibular surface of the three teeth was processed for 10 seconds without the use of toothpaste. Tooth № 1 was a control (biofilm was not removed), tooth № 2 was cleaned with a manual toothbrush with an imitation of the Brass method, tooth № 3 was cleaned with a brush with oscillating-rotating movements of bristles. Tooth № 4 was brushed with a toothbrush with vibrating types of bristles motion. The enamel-cementum junction of the tooth was taken strictly from the vestibular surface along the central axis of the tooth for studying in a scanning electron microscope. Conclusions. A complete cleaning of the tooth enamel surface from microbial biofilms is not achieved after using a manual toothbrush. Toothbrushes with oscillating-rotating movements of bristles create the phenomenon of "sweeping" of the biofilm fragments into the area of the cementum-enamel junction. The vibrating types of bristles motion maximally clean the cervical area of the tooth.
\end{abstract}

\section{Сравнительная оценка эффективности уАаления зубного налета с поверхности зуба с помощью электрических зубных щеток с разАичными типами Авижения щетинок}

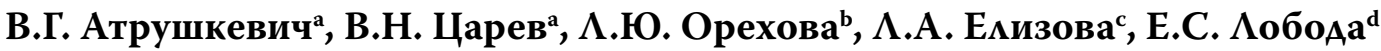

${ }^{\mathrm{a}} \mathrm{A}$-р меА. наук, профессор, Московский государственный меАико-стоматологический университет им. А.И. ЕвАокимова, Москва, Россия ${ }^{\mathrm{b}} \mathrm{A}-\mathrm{p}$ меА. наук, профессор, Первый Санкт-Петербургский государственный меАицинский университета им. акаА. И.П. Павлова, Санкт-Петербург, Россия

сканА. меА. наук, Московский государственный медико-стоматологический университет им. А.И. ЕвАокимова, Москва, Россия ${ }^{\mathrm{d}}$ канА. меА. наук, Аоцент, Первый Санкт-Петербургский государственный медицинский университета им. акаА. И.П. Павлова, СанктПетербург, Россия

doi: $10.32993 /$

stomatologist.2018.4(31).11

Поступима в редакцию 26.10.18

Принята к печати 30.10.18

Киючевые слова: микробные биопиенки, пародонтит, электрические зубные щетки

\section{PЕЗЮМЕ}

Введение. ПодАерживающая пародонтальная" терапия (ППТ) является важным фактором в сохранении результатов активного мечения заболеваний пародонта". Кроме формирования устойчивых гигиенических навыков у пациентов, очень важен подбор эффективных средств инАивиАуальной гигиены. Цемью исслеАования явилась сравнительная оценка качества механического удаления нативной микробной биопкенки зубными щетками с разАичным типом вращения головки и мануальной зубной щеткой. Объекты и методы. УАаленные зубы были зафиксированы в гипсовые модеми, и вестибулярная поверхность трех зубов обработана в течение 10 секунд без испомьзования зубной пасты. Зуб № 1- контромь (биопленка не удацялась), зуб № 2 - почищен мануацьной зубной щеткой с имитацией метода Brass, зуб № 3 - почищен щеткой с возвратно-вращательными Авижениями щетинок, зуб № 4 - почищен зубной щеткой с возвратно-поступательными Авижениями щетинок. Аля изучения в сканирующем электронном микроскопе брали область эмалево-цементного соединения зуба строго с вестибулярной поверхности по центральной оси зуба. Закмючение. При использовании мануальной зубной щётки не достигается помноценной очистки поверхности эмали зуба от микробных биоплёнок. Зубные щетки с возвратно-поступательным Авижением головки создают феномен «заметания» фрагментов биоплёнки в область цементно-эмалевого соединения. Возвратно-поступательное Авижения щетинок зубной щетки максимально качественно очищает пришеечную область зуба.

Correspondence to /

E-mail:

Аарес Аля корреспонденции:

atrushkevichv@mail.ru 
$\mathrm{P}$ eriodontal maintenance (PM) is an important factor in supporting results of active periodontal treatment. A special role in PM efficacy belongs to good oral hygiene. Multiple studies of different types of oral care products showed that amount of supragingival plaque affects the number of subgingival periodontal pathogens. The research also proved that the length of periodontal disease remission depends on the level of oral care. Besides the formation of good oral habits, it is also very important to choose effective tools for home oral care. Data of epidemiological surveys show high population awareness about available oral care products. However, the study conducted by the Department of Periodontology of MSUMD shows that only $48.5 \%$ of questioned patients use water flossers on a regular basis and only $15.2 \%$ brush their teeth with electric toothbrush. It is interesting that $16.3 \%$ of participants ever bought a water flosser and $15.1 \%$ of patients got an electric toothbrush, but they don't use them as intended due to lack of knowledge about their efficacy $[1,2,6,7]$.

\section{THE AIM OF THE STUDY}

Therefore the aim of our study is a comparative evaluation of the quality of dental plaque removal by electric toothbrushes with different types of bristle movement and manual toothbrushes.

\section{- OBJECTS AND METHODS}

Patient G., DoB 1981, with aggressive periodontitis had 4 incisors extracted simultaneously due to periodontal disease (fig. 1, 2).

The teeth were placed in sterile saline for 30 minutes. Biofilm was not removed from one tooth (control). Three teeth were mounted in plaster and their labial surface was cleaned during 10 seconds without paste in a wet medium with various toothbrushes: manual and electric (oscillating-rotating and vibrating types of bristle motion).

For imaging in scanning electron microscope (SEM) teeth were fixed with $10 \%$ neutral buffered formalin, then frozen samples were dehydrated in graded ethanol series. After dehydration, the samples were dried in Quorum K350 (Quorum GaLa Instrumente GmbH, Germany). Prepared samples were mounted on a special aluminium table with conductive carbon glue and sputter-coated with gold or platinum-palladium alloy in Quorum Q150TS system (Quorum GaLa Instrumente GmbH, Germany) and studied in SEM S 3400N (Hitachi, Japan) at accelerating voltage.

\section{RESULTS AND DISCUSSION}

Nowadays it is proved that biofilm growth is stimulated by anaerobic conditions due to reducing features of mucin, oligosaccharides of oral fluid, food debris. Therefore multi-species biofilm formation is more pronounced in the deepest parts of the gingival sulcus specifically on the tooth surface at the cementoenamel junction that is visible on SEM images of the present study samples (fig. 3) [3, 4].

Analyzing SEM images it was found out that at high magnification biofilm structure with various morphologic forms is well distinguished (fig. 4). In some parts coccal, filamentous and rodshaped elements are more distinct. The last are numerous in chronic periodontitis and identified with the application of molecular diagnostic techniques as bacteroid forms. According to data of E.V. Ippolitov (2016) they belong to periodontal pathogens of the bacteroid group - P. gingivalis, P. intermedia, $\mathrm{T}$. forsythia $[1,2]$.

According to our results, different products for mechanical removal of microbial biofilm from tooth enamel and root cementum apparently change in a certain way morphological pattern as observed with SEM and demonstrated in the images below.

The minimal difference is detected between an almost "uncleaned tooth" and cleaned with a manual toothbrush. Tooth surface is irregularly covered with biofilm and apparently clean areas interchange with microbial accumulation (fig. 5).

Area of CEJ shows "sweeping" phenomenon, i.e. reaggregation of biofilm fragments and selected groups of microbial cells (fig. 6, 7). At that, significant accumulation of microbial cells is marked in deep areas, on root cementum (fig. 8, 9). Typical multilayered structure of mixed culture biofilm is observed $[1,2,5]$.

The result was different when oscillation-rotation cleaning system (Oral-B) was used. All biofilm was removed from tooth enamel; its surface was quite smooth and free from microbial forms with single inclusions within the field of view (fig. 10a). It is visible at higher magnification that those are separate, very small fragments of biofilm. At that distinct bacterial forms are not defined (Fig. 10b).

Thus, manual toothbrushing cannot properly remove microbial biofilm from tooth enamel. Minimal effect of mechanical cleaning is marked at gingival attachment area and especially at CEJ.

The image was different at the CEJ level. Biofilm on tooth cementum was almost intact (fig. 11) and microbiota composition, as seen at higher magnification in this area, was more diverse and 


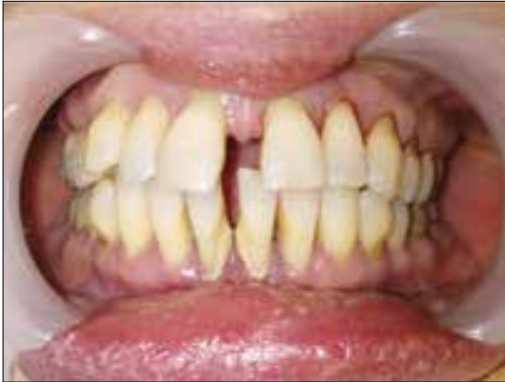

Fig. 1. Patient G., 1981, diagnosis: aggressive periodontitis. Condition before tooth extraction

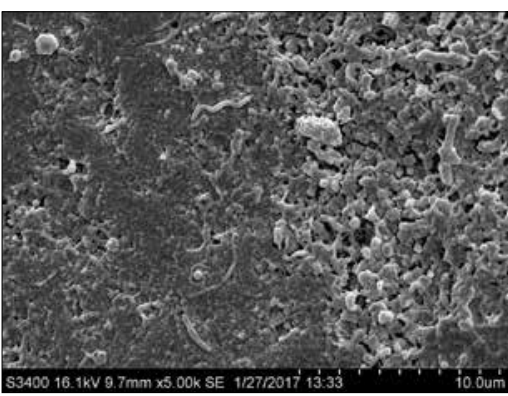

Fig. 4. Coccal, filamentous and bacteroid morphotypes in mixed culture biofilm in CEJ area. SEM. Mag. 9.7x5.00k ("high»)

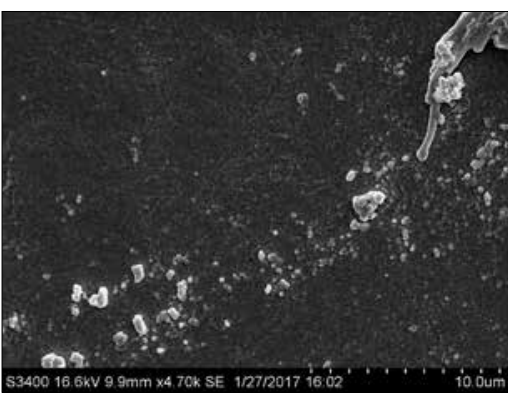

Fig. 7. Distinct groups of coccal and bacteroid morphological forms SEM. Mag. 9.9x4.70k ("high")

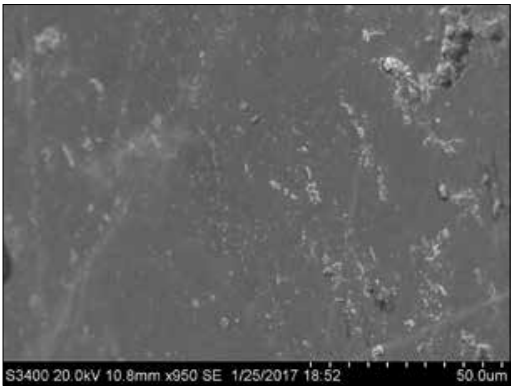

Fig. 10a. Tooth enamel surface SEM. Mag $10.8 \times 950 \mathrm{SE}$

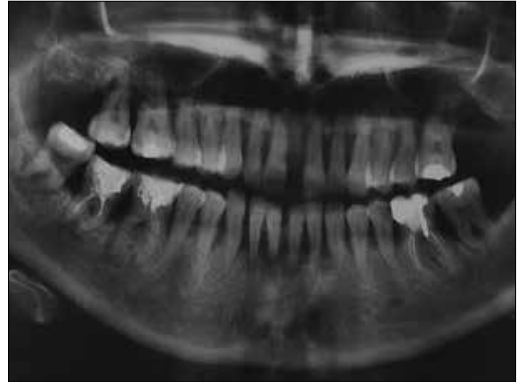

Fig. 2. Patient G., 1981, aggressive periodontitis. OPG

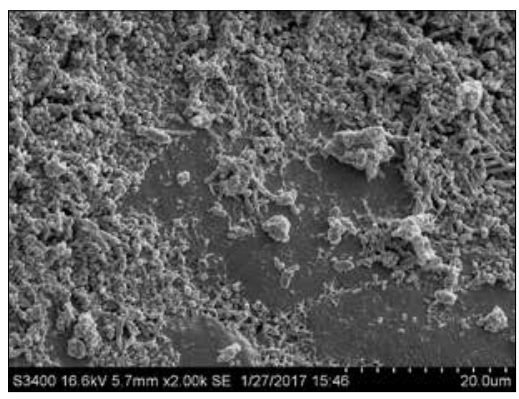

Fig. 5. Tooth surface above the attached gingiva after thorough brushing with a manual toothbrush. SEM. Mag. $5.7 \times 2.00 \mathrm{k}$ ("medium")

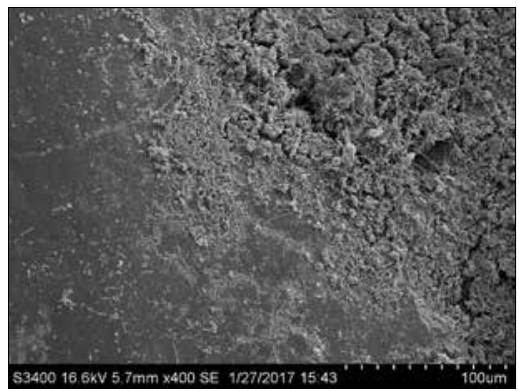

Fig. 8. Preserved mixed culture biofilm in CEJ area. SEM. Mag. 5.7x4.00k ("medium")

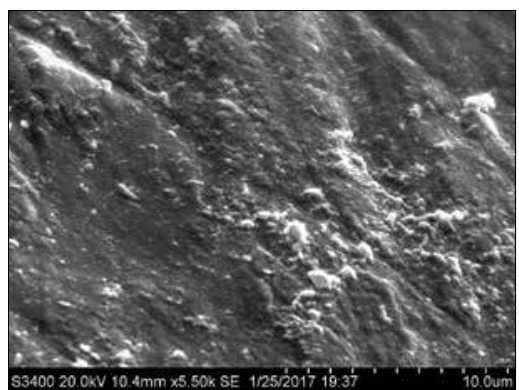

Fig. 10b. Tooth enamel surface. SEM. Mag. 10.4x5.50k ("high")

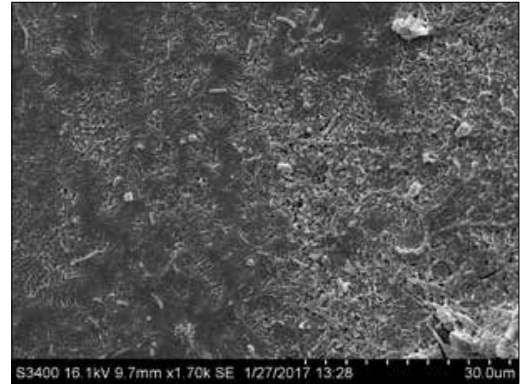

Fig. 3. Overview of mixed culture biofilm in CEJ area. SEM. Mag. 9.7x1.70k ("medium")

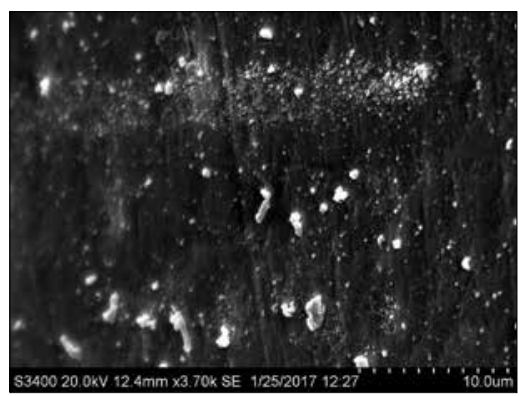

Fig. 6. The irregular distribution of biofilm and selected groups of microbial cells the phenomenon of toothbrush "sweeping" SEM. Mag. 12.4×3.70k ("high")

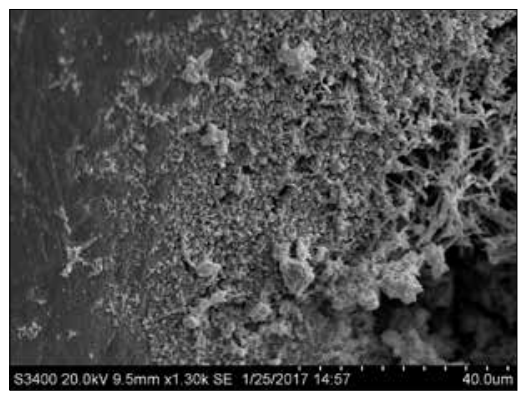

Fig. 9. The multilayered structure of preserved mixed culture biofilm at CEJ. SEM. Mag. 9.5x1.30k ("high")

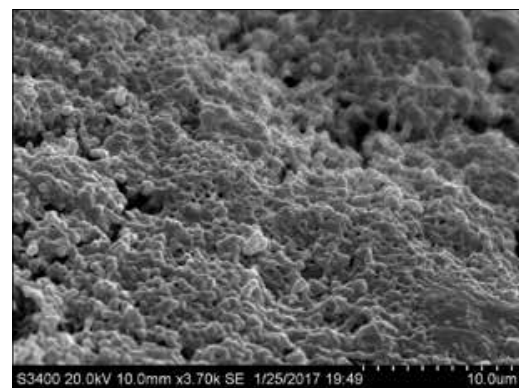

Fig. 11. Thick biofilm covering root cementum. SEM. Mag. 10.0x3.70k ("medium") 


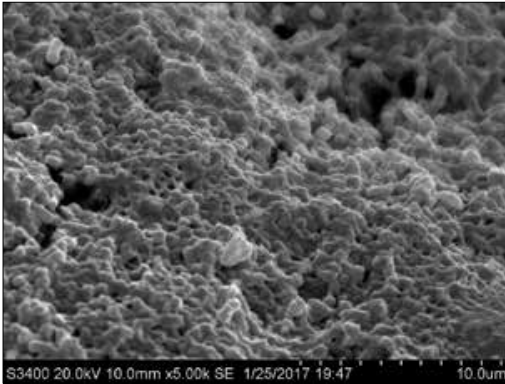

Fig. 12. Thick biofilm covering root cementum. SEM. Mag. 10.0×5.00k ("high")

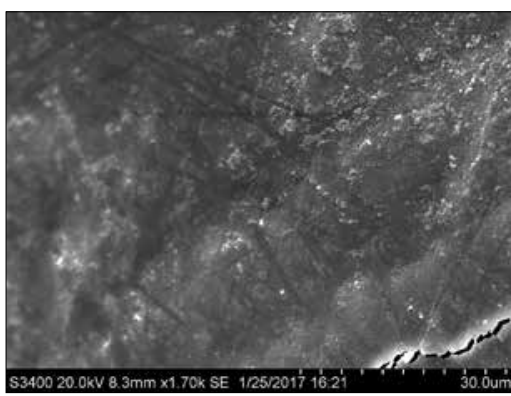

Fig. 15. Tooth enamel surface. SEM. Mag. $8.3 \times 1.70 k$ ("low")

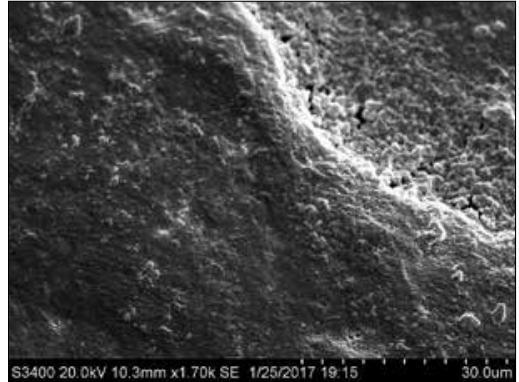

Fig. 13. The irregular distribution of biofilm "sweeping" phenomenon by Oral-B cleaning system. SEM. Mag. 10.3x1.70k («medium»)

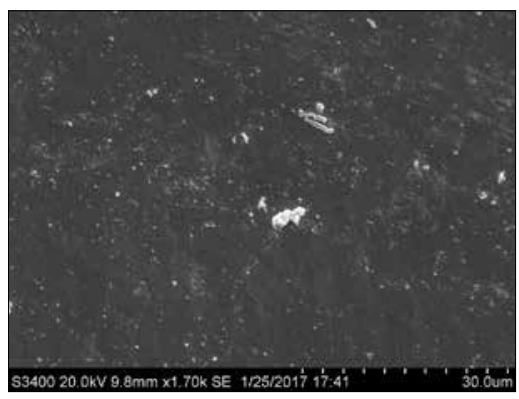

Fig. 16. Tooth enamel surface. SEM. Mag. 9.8x1.70k ("medium")

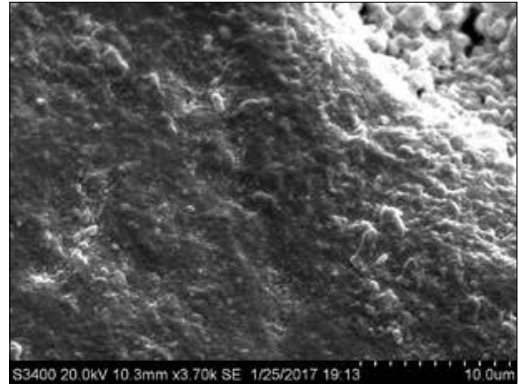

Fig. 14. The irregular distribution of biofilm "sweeping" phenomenon by Oral-B cleaning system. SEM. Mag. 10.3×3.70k ("high")

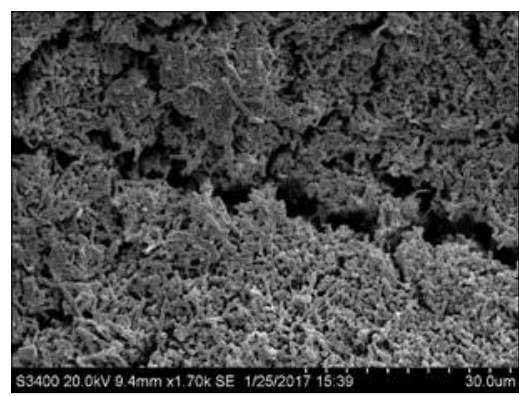

Fig. 17. Fragmented multi-layered biofilm on root cementum after cleaning by Philips system. SEM. Mag. 9.4x1.70k ("medium")

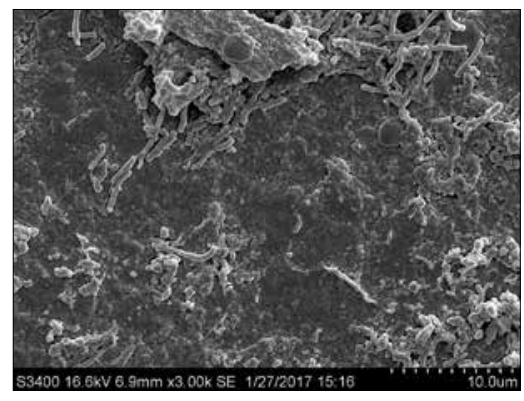

Fig. 18. Selected structures of biofilm on root cementum after cleaning by Philips system. SEM. Mag. 9.4x1.70k ("medium")

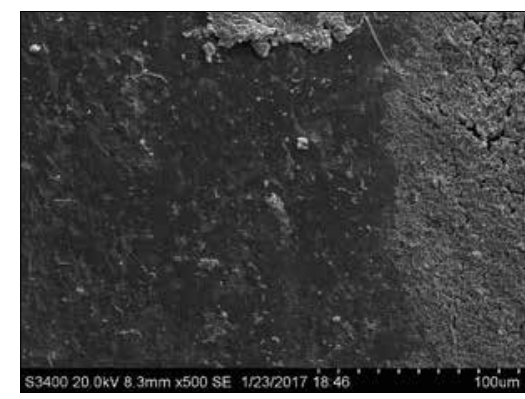

Fig. 19. Cementoenamel junction: biofilmfree (on the left) and biofilm-populated (on the right) after cleaning by Philips system. SEM. Mag. 8.3×500 SE ("low»)

oscillating-rotating toothbrushes. However fragmented biofilm layers were revealed by the study. It seems that biofilm is partially destroyed (fig. 17) in comparison with fig. 11.

It was found out that in some areas multilayered structure of biofilm was lost and biofilm thickness decreased, that can be associated with the present type of cleaning, but needs to be specified by quantitative methods (fig. 18).

Most distinguished differences from two studied and above-mentioned types of brushing were detected at cementoenamel junction. Specifically, there were large biofilm-free areas (fig. 19). 


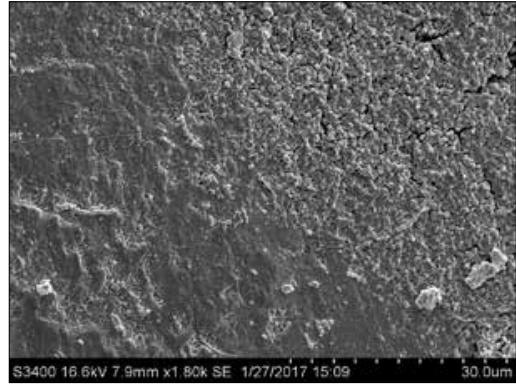

Fig. 20. Biofilm in cementoenamel junction area after cleaning by Philips system. No signs of "sweeping". SEM. Mag. 7.9x1.80k ("medium").

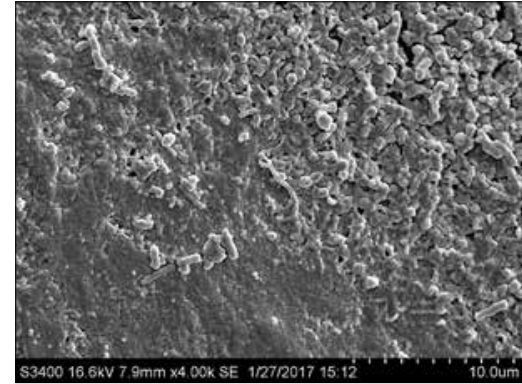

Fig. 21. Biofilm in the area of cementoename junction after brushing by Philips system. Dominance of cocci. SEM. Mag. 7.9x4.00k ("medium").
At higher magnification, the microbial biofilm is visible without distinct structure (fig. 20). Signs of "sweeping" detected in two previous cleaning options were not revealed after the Philips system application. Coccal morphological type visually dominates over bacteroid that can be considered as a favourable sign in the prognosis of decrease of inflammation and regression of periodontitis (fig. 21) [2].

\section{CONCLUSION}

Thus, according to SEM, manual brushing cannot properly remove microbial biofilm from tooth enamel and rotation-oscillation technologies (Oral-B) create the phenomenon of "sweeping" of biofilm fragments to CEJ area though partially clean tooth surface and destroy biofilm.

Minimal effect of mechanical cleaning in all types of brushing including powered brushing is seen at gingival attachment level and especially at the level of the cementoenamel junction. The efficiency of Sonicare FlexCare Platinum (Philips) is proved not only by quality cleaning of enamel surface due to dynamic fluid flow but by the absence of "sweeping" phenomenon in the CEJ area after bristle vibrations.

Besides, it is reasonable to perform quantitative tests in vitro in an experiment with modulated biofilm and quantitative evaluation of decrease of bacterial load in CEJ area to confirm suggested positive effect of Philips system.

\section{- Conflict of interest}

The authors declare no conflict of interest /Авторы заявили об отсутствии конфликта интересов

\section{Publication ethics}

Positive opinion of the local ethics committee at MSMDU received from 20/12/2018 / Положительное заключение локального комитета по этике при МГМСУ получено от 20.12.2018

\section{References}

1. Ippolitov E.V., Didenko L.V., Tcarev V.N. Osobennosti morfologii bioplyonki parodonta pri vospalitel'nyh zabolevaniyah dyosen (hronicheskij kataral'nyj gingivit, hronicheskij parodontit, kandida-associirovannyj parodontit) po dannym ehlektronnoj mikroskopii [Features of the morphology of periodontal biofilms in inflammatory diseases of the gums (chronic catarrhal gingivitis, chronic periodontitis, candida-associated periodontitis) according to electron microscopy]. Klinicheskaya laboratornaya diagnostika. - Clinical laboratory diagnostics, 2015, vol. 60, no. 12, pp. 59-64.

2. Rybal'chenko O.V., Orlova O.G., Vishnevskaya O.N. [et al.] Osobennosti formirovaniya bakterial'nyh bioplyonok v usloviyah kosmicheskogo polyota [Features of the formation of bacterial biofilms in space flight]. Zhurnal mikrobiologii, ehpidemiologii i immunobiologii. - Journal of Microbiology, Epidemiology and Immunobiology, 2017, no. 6, pp. 3-10.

3. Tcarev V.N., Ippolitov E.V., Trefilov A.G., Arutyunov S.D., Pivovarov A.A. Osobennosti adgezii anaehrobnyh parodontopatogennyh bakterij i gribov Candida albicans k ehksperimental'nym obrazcam bazisnoj stomatologicheskoj plastmassy v zavisimosti ot sherohovatosti poverhnosti i sposoba polirovki [Features of adhesion of anaerobic periodontopathogenic bacteria and fungi Candida albicans to experimental samples of basic dental plastic, depending on the surface roughness and method of polishing]. Zhurnal mikrobiologii, ehpidemiologii i immunobiologii. - Journal of microbiology, epidemiology and immunobiology, 2014, no. 6, pp. 21-27.

4. Tcarev V.N., Atrushkevich V.G., Ippolitov E.V., Podporin M.S. Sravnitel'nyj analiz antimikrobnoj aktivnosti parodontal'nyh antiseptikov s ispol'zovaniem avtomatizirovannoj sistemy kontrolya rosta mikroorganizmov v rezhime real'nogo vremeni [Comparative analysis of antimicrobial activity of periodontal antiseptics using an automated system for controlling the growth of microorganisms in real time]. Parodontologiya. Periodontics, 2017, no. 1, pp. 4-10.

5. Mager D.L., Ximenez-Fyvie L.A., Haffajee A.D., Socransky S.S. Distribution of selected bacterial species on intraoral surfaces. J Clin Periodontol., 2003, no. 30(7), pp. 644-654, doi.org/10.1034/j.1600-051x.2003.00376.x

6. Teles R., Teles F., Frias-Lopez J., Paster B., Haffajee A. Lessons learned and unlearned in periodontal microbiology. Periodontol, 2000-2013, no. 62 (1), pp. 95-162, doi.org/10.1111/prd.12010

7. König J., Storcks V., Kocher T., Bössmann K., Plagmann H.C. Anti-plaque effect of tempered $0.2 \%$ chlorhexidine rinse: an in vivo study. J Clin Periodontol, 2002, no. 29(3), pp. 207-210, doi.org/10.1034/j.1600-051x.2002.290304.x

8. Costa F.O., Cota L.O., Lages E.J., Lima Oliveira A.P., Cortelli S.C., Cortelli J.R., Lorentz T.C., Costa J.E. Periodontal risk assessment model in a sample of regular and irregular compliers under maintenance therapy: a 3-year prospective study. J Periodontol, 2012, no. 83 (3), pp. 292-300, doi.org/10.1902/jop.2011.110187 


\section{Литература}

1. Ипполитов, Е.В. Особенности морфологии биоплёнки пародонта при воспалительных заболеваниях дёсен (хронический катаральный гингивит, хронический пародонтит, кандида-ассоциированный пародонтит) по данным электронной микроскопии. /

Е.В. Ипполитов, Л.В. Диденко, В.Н. Царев // Клиническая лабораторная диагностика. - 2015. - Т. 60, - № 12. - С. 59-64.

2. Рыбальченко, О.В. Особенности формирования бактериальных биоплёнок в условиях космического полёта. / О.В. Рыбальченко,

О.Г. Орлова, О.Н. Вишневская и соавт // Журнал микробиологии, эпидемиологии и иммунобиологии. - 2017. - № 6. - С. 3-10.

3. Царев, В.Н. Особенности адгезии анаэробных пародонтопатогенных бактерий и грибов Сandida albicans к экспериментальным

образцам базисной стоматологической пластмассы в зависимости от шероховатости поверхности и способа полировки. / Царев В.Н., Ипполитов Е.В., Трефилов А.Г., Арутюнов С.Д., Пивоваров А.А. // Журнал микробиологии, эпидемиологии и иммунобиологии. - 2014. № 6. - С. 21-27.

4. Царев, В.Н. Сравнительный анализ антимикробной активности пародонтальных антисептиков с использованием автоматизированной системы контроля роста микроорганизмов в режиме реального времени. / В.Н. Царев, В.Г. Атрушкевич, Е.В. Ипполитов, М.С. Подпорин // Пародонтология. - 2017. - № 1. - С.4-10.

5. Mager D.L., Ximenez-Fyvie L.A., Haffajee A.D., Socransky S.S. Distribution of selected bacterial species on intraoral surfaces. J Clin Periodontol., 2003, no. 30(7), pp. 644-654, doi.org/10.1034/j.1600-051x.2003.00376.x

6. Teles R., Teles F., Frias-Lopez J., Paster B., Haffajee A. Lessons learned and unlearned in periodontal microbiology. Periodontol, 2000-2013, no. 62 (1), pp. 95-162, doi.org/10.1111/prd.12010

7. König J., Storcks V., Kocher T., Bössmann K., Plagmann H.C. Anti-plaque effect of tempered $0.2 \%$ chlorhexidine rinse: an in vivo study. J Clin Periodontol, 2002, no. 29(3), pp. 207-210, doi.org/10.1034/j.1600-051x.2002.290304.x

8. Costa F.O., Cota L.O., Lages E.J., Lima Oliveira A.P., Cortelli S.C., Cortelli J.R., Lorentz T.C., Costa J.E. Periodontal risk assessment model in a sample of regular and irregular compliers under maintenance therapy: a 3-year prospective study. J Periodontol, 2012, no. 83 (3), pp. 292-300, doi.org/10.1902/jop.2011.110187

\section{«МЕЖАУНАРОАНАЯ СПЕЦИААИЗИРОВАННАЯ СТОМАТО ООГИЧСКАЯ ВЫСТАВКА "KAZDENTEXPO-2019"»}

Аата провеАения: 5-7 июня 2019 г.

Место проведения: Казахстан, Аворец спорта им. Бакуана Шолака, пр. Абая, 44. Организатор: DENTALEXPO Официамьный сайт: http://www.dental-expo.com/kazdent.html 